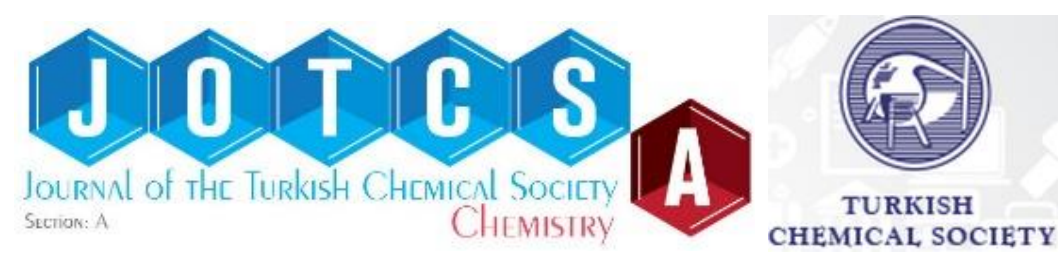

\title{
Binder Effect on Electrochemical Performance of Zinc Electrodes For Nickel-Zinc Batteries
}

\author{
${ }^{1}$ Gizem CìHANOĞLU, 1,a Özgenç EBİL \\ Department of Chemical Engineering, İzmir Institute of Technology, Izmir, Turkey
}

(This article first appeared in PPM2017 and was accepted as a non-peer-reviewed manuscript to be published in JOTCSA)

\begin{abstract}
Polyethylene glycol (PEG) and polyvinyl alcohol (PVA) were used as a zinc electrode binder at different concentrations to enhance the electrochemical behavior of zinc electrodes for nickel-zinc $(\mathrm{NiZn})$ batteries. ZnO powders synthesized by mechanochemical and hydrothermal precipitation methods were mixed with lead oxide, calcium hydroxide and binder to prepare zinc electrodes in pouch cell NiZn batteries. Scanning Electron Microscopy (SEM) and X-Ray Diffraction (XRD) analysis reveal that initial morphology of zinc electrode changes drastically regardless of the binder type and its loading after charge/discharge process, and even the charge/discharge process is not complete. The results show that the presence of PEG causes better discharge capacity compared to that of PVA as a binder. Zinc electrode prepared using commercial ZnO powder and $3 \mathrm{wt}$ \% PEG gives the optimum discharge capability, with a specific capacity of approximately $311 \mathrm{mAhg}^{-1}$, while zinc electrodes prepared using $\mathrm{ZnO}$ powder synthesized from $\mathrm{ZnCl}_{2}$ and $\mathrm{Zn}\left(\mathrm{NO}_{3}\right)_{2} .6 \mathrm{H}_{2} \mathrm{O}$ and $6 \mathrm{wt}$.\% PEG exhibit high specific energy of 255 and $275 \mathrm{mAhg}^{-1}$, respectively. The results suggest a relationship between binder loading and battery capacity, but in-situ analysis of microstructural evolution of zinc electrode during charge/discharge process is needed to confirm this relationship.
\end{abstract}

Keywords: Zinc electrode, NiZn secondary batteries, PEG, PVA.

Cite this: Cihanoğlu G, Ebil Ö. Binder Effect on Electrochemical Performance of Zinc Electrodes For Nickel-Zinc Batteries. JOTCSA. 2018;5(sp.is.1):65-84.

*Corresponding author. E-mail. ozgencebil@iyte.edu.tr 


\section{INTRODUCTION}

The nickel-zinc battery is one of the most significant energy storage systems for various electrical applications due to moderate specific energy (55-85 $\mathrm{Whkg}^{-1}$ ), high power density (140-200 Whkg $\left.{ }^{-1}\right)$, high open circle potential $(1.705 \mathrm{~V})$, and a nominal cell voltage of $1.6 \mathrm{~V}$ [1-2]. Nickelzinc batteries have attractive advantages such as being low cost, environmentally friendly and having abundant resources for raw materials. However, these kind of batteries have not reached their full potentials mostly due to critical problems. These problems are attributed to shape change of zinc electrode with increasing charge/discharge cycle count, zinc electrode passivation, and dendritic zinc growth leading to short-circuiting of the battery. During discharge process, zincate ion $\left(\mathrm{Zn}(\mathrm{OH}) 4^{2-}\right)$ in the alkaline electrolyte is formed before zinc oxide precipitates. During charging process, the concentration of zincate ions near the bottom of the electrode decreases and zincate ions are precipitated as zinc oxide when the limit of solubility is reached. This process leads shape change and the formation of dendrite of zinc as well as the protrusion on the surface of zinc electrode with increasing number of charge/discharge cycles. Passivation is also another serious problem for deterioration of zinc-based batteries. The passivation of zinc electrode occurs when the solubility of zincate is exceeded in electrolyte close to the surface of the zinc electrode, and an insulating ZnO barrier layer is formed on electrode surface [3-5]. As a result of these issues, short cycle life and/or poor electrochemical performance have limited the wide-range application of NiZn batteries. Many attempts have been made to overcome these problems. One approach is to use additives in either electrode [6-9] or electrolyte [10-12]. Another one is to fabricate an electrode including different morphology and size of zinc oxide [13-15]. Some of oxide additives used in zinc electrode, such as $\mathrm{Ca}(\mathrm{OH})_{2}[16,17], \mathrm{Bi}_{2} \mathrm{O}_{3}[18], \mathrm{PbO}[19], \mathrm{TiO}_{2}$ [20], and $\mathrm{In}_{2} \mathrm{O}_{3}[21]$ are convenient to decrease the concentration of the zinc oxidation products and improve electronic conductivity and current distribution [17]. Binders or gels, such as sodium silicate [22], tapioca [23], polytetrafluoroethylene $[24,25]$, carbopol gel $[26,27]$, and sago [28], are ways to improve the active material utilization and effective surface area in zinc electrode.

Many organic additives in alkaline solutions are used as zinc corrosion inhibitors. Polyethylene glycol (PEG) is suitable for binding agent in electrode preparation to inhibit zinc corrosion. EinEli and co-workers investigated the effect of PEG with a molecular weight $600 \mathrm{kgkmol}^{-1}$ and polyoxyethylene alkyl phosphate ester acid (GAFAC RE600) on zinc metal electrode [29]. The results showed that the electrochemical studies represented PEG in alkaline solution had much more efficient inhibition capability compared to GAFAC RA600 [29].

Additionally, poly(vinylalcohol) (PVA) which is one of the alkaline polymers are also used as a binder to enhance ionic conductivity of electrolyte and electrode. The influence of PVA and KOH in polymer electrolytes on ionic conductivity of electrolyte was investigated by Mohamad et al. [17]. The result of this study indicated that the capacity was found to be $5.5 \mathrm{mAh}$ at the end of 
100 cycles [17]. In another study, polymer gel electrolyte with 60:40 ratio in zinc-carbon cell was examined by Saleem et al. [30]. It was observed that the current charge/discharge efficiency was found to be $57 \%$ [30]. Wu and co-workers focused on the PVA-KOH-TiO 2 alkaline polymer solid electrolyte in NiZn batteries [31]. It was reported that the specific capacity of PVA$\mathrm{KOH}-\mathrm{TiO}_{2}$ polymer electrolyte, $250 \mathrm{mAhg}^{-1}$, was higher in comparison with the specific energy of PVA-KOH polymer electrolyte, $190 \mathrm{mAhg}^{-1}[31]$.

In our previous paper, we reported the preparation of prismatic NiZn batteries with various initial zinc electrode morphologies [32]. ZnO powders were synthesized from different precursors, $\mathrm{ZnCl}_{2}$ and $\mathrm{Zn}\left(\mathrm{NO}_{3}\right)_{2} .6 \mathrm{H}_{2} \mathrm{O}$ to fabricate zinc electrodes for prismatic NiZn batteries. It was found that initial morphology of zinc electrode had an effect on electrode discharge capacity. The resulting $\mathrm{ZnO}$ electrodes with $\mathrm{ZnO}$ powders synthesized from $\mathrm{ZnCl}_{2}$ and $\mathrm{Zn}\left(\mathrm{NO}_{3}\right)_{2}$ demonstrated average battery energy densities varying between $92 \mathrm{Whkg}^{-1}$ and $109 \mathrm{Whkg}^{-1}$ whereas with conventional ZnO powder gave higher energy density of $118 \mathrm{Whkg}^{-1}$ [32].

Herein, we present zinc electrode prepared using binder, PEG or PVA, with different concentrations for the pouch cell NiZn batteries. The various zinc oxide structures were also prepared by different processes. Additionally, the various loadings of binders for porous zinc electrode $(3,6$ and $12 \mathrm{wt} . \%)$ to achieve the battery performance were explored. The aim of this work was to fabricate a nickel-zinc battery by employing PEG and PVA as the binder for the porous zinc electrode and to determine the optimum composition of binder. Morphological studies of zinc oxide as active material for the porous electrode were used to promote the findings.

\section{MATERIALS AND METHODS}

\section{Preparation of ZnO powders}

$\mathrm{ZnO}$ powders with different morphologies were synthesized from $\mathrm{ZnCl}_{2}$ and $\mathrm{Zn}\left(\mathrm{NO}_{3}\right)_{2} .6 \mathrm{H}_{2} \mathrm{O}$ precursors following the method reported previously [32]. Nanosized spherical and plate-like shaped ZnO particles were prepared by simple precipitation method. Briefly, in the first precipitation method, $100 \mathrm{~mL}$ solution containing $0.2 \mathrm{M} \mathrm{KOH}$ and $0.02 \mathrm{M}$ triethanolamine (TEA) was mixed with $100 \mathrm{~mL}$ of $0.1 \mathrm{M} \mathrm{ZnCl}_{2}$ solution under ultrasonic treatment (WUC-D06H, Wisd) at $50^{\circ} \mathrm{C}$. The precipitate was separated by centrifuging (Sigma, 3-16 PK) at room temperature. The solid phase was washed with $0.1 \mathrm{M} \mathrm{NH}_{4} \mathrm{OH}$ solution three times. Finally, the solid phase was dried at $50^{\circ} \mathrm{C}$, then baked at $200^{\circ} \mathrm{C}$ in oven.

In precipitation method for nanosized plate-like shaped $\mathrm{ZnO}, 100 \mathrm{ml}$ of $1 \mathrm{M} \mathrm{Zn}\left(\mathrm{NO}_{3}\right)_{2} .6 \mathrm{H}_{2} \mathrm{O}$ solution, $27.85 \mathrm{ml}$ of $8 \mathrm{M} \mathrm{NaOH}$ and $22.15 \mathrm{~mL}$ of ultrapure water were mixed to obtain a desired $\mathrm{pH}$ value. $\mathrm{NaOH}$ solution and ultrapure water were added into $\mathrm{Zn}\left(\mathrm{NO}_{3}\right)_{2} \cdot 6 \mathrm{H}_{2} \mathrm{O}$ solution while stirring in a magnetic stirrer at $20^{\circ} \mathrm{C}$. As-prepared solution was aged at $20^{\circ} \mathrm{C}$ for 30 minutes. The 
precipitate was separated by centrifuging. The solid phase was washed with ultrapure water three times. Finally, the solid phase was dried at $50^{\circ} \mathrm{C}$, and then baked at $200^{\circ} \mathrm{C}$ in oven.

The morphologies of commercial ZnO powder (KIMETSAN, 99\%), powders produced by mechanochemical methods at elevated temperatures were characterized by powder $X$-ray diffraction (XRD, Phillips ${ }^{\mathrm{TM}}$ Xpert diffractometer with $\mathrm{Cu}$ Ka radiation) and scanning electron microscope (SEM, FEI Quanta250).

\section{Preparation of electrodes for test cells}

In order to minimize the time for electrical characterization and materials use, only $1 \mathrm{gram}$ of zinc oxide powder was used in zinc electrodes in all experiments. Zinc electrodes with different compositions were prepared. Details of zinc electrodes are summarized in Table 1. Zinc electrode paste was prepared by mechanically mixing zinc oxide, calcium hydroxide ( $3 \mathrm{wt} . \%$ ), lead oxide (1 wt. \%), polyethyleneglycol or polyviniylalcohol as binders (300 $\mathrm{LL}$ aqueous solution), and 100 $\mu \mathrm{L}$ of $10 \mathrm{wt} . \% \mathrm{KOH}$ solution. The binder loading was varied between 3 and $12 \mathrm{wt}$. The paste was applied onto a $40 \mu \mathrm{m}$ thick craft paper to form a uniform layer and a copper wire was placed on top as current collector. The craft paper was then folded and sealed to obtain a zinc electrode 2 $\mathrm{cm} \times 2 \mathrm{~cm}$ in size. To make sure that there is a good contact between current collector and zinc electrode, electrodes were tightly sealed under pressure. 
Table 1: Zinc electrode samples.

\begin{tabular}{|c|c|c|}
\hline $\begin{array}{c}\text { Sample } \\
\text { name }\end{array}$ & Contents & $\begin{array}{l}\text { Composition } \\
\text { ratio }\end{array}$ \\
\hline A1 & ZnO from $\mathrm{ZnCl}_{2}$ :calcium hydroxide:lead oxide:PEG & $93: 3: 1: 3$ \\
\hline A2 & $\mathrm{ZnO}$ from $\mathrm{ZnCl}_{2}$ :calcium hydroxide:lead oxide:PEG & $90: 3: 1: 6$ \\
\hline A3 & $\mathrm{ZnO}$ from $\mathrm{ZnCl}_{2}$ :calcium hydroxide:lead oxide:PEG & $84: 3: 1: 12$ \\
\hline A4 & $\mathrm{ZnO}$ from $\mathrm{ZnCl}_{2}$ :calcium hydroxide:lead oxide:PVA & $93: 3: 1: 3$ \\
\hline A5 & $\mathrm{ZnO}$ from $\mathrm{ZnCl}_{2}$ :calcium hydroxide:lead oxide:PVA & $90: 3: 1: 6$ \\
\hline A6 & $\mathrm{ZnO}$ from $\mathrm{ZnCl}_{2}$ :calcium hydroxide:lead oxide:PVA & $84: 3: 1: 12$ \\
\hline B1 & $\mathrm{ZnO}$ from $\mathrm{Zn}\left(\mathrm{NO}_{3}\right)_{2} \cdot 6 \mathrm{H}_{2} \mathrm{O}$ :calcium hydroxide:lead oxide:PEG & $93: 3: 1: 3$ \\
\hline B2 & $\mathrm{ZnO}$ from $\mathrm{Zn}\left(\mathrm{NO}_{3}\right)_{2} \cdot 6 \mathrm{H}_{2} \mathrm{O}$ :calcium hydroxide:lead oxide:PEG & $90: 3: 1: 6$ \\
\hline B3 & $\mathrm{ZnO}$ from $\mathrm{Zn}\left(\mathrm{NO}_{3}\right)_{2} \cdot 6 \mathrm{H}_{2} \mathrm{O}$ :calcium hydroxide:lead oxide:PEG & $84: 3: 1: 12$ \\
\hline B4 & $\mathrm{ZnO}$ from $\mathrm{Zn}\left(\mathrm{NO}_{3}\right)_{2} \cdot 6 \mathrm{H}_{2} \mathrm{O}$ :calcium hydroxide:lead oxide:PVA & $93: 3: 1: 3$ \\
\hline B5 & $\mathrm{ZnO}$ from $\mathrm{Zn}\left(\mathrm{NO}_{3}\right)_{2} \cdot 6 \mathrm{H}_{2} \mathrm{O}$ :calcium hydroxide:lead oxide:PVA & $90: 3: 1: 6$ \\
\hline B6 & $\mathrm{ZnO}$ from $\mathrm{Zn}\left(\mathrm{NO}_{3}\right)_{2} \cdot 6 \mathrm{H}_{2} \mathrm{O}$ :calcium hydroxide:lead oxide:PVA & $84: 3: 1: 12$ \\
\hline $\mathrm{C} 1$ & commercial ZnO:calcium hydroxide:lead oxide:PEG & $93: 3: 1: 3$ \\
\hline $\mathrm{C} 2$ & commercial ZnO:calcium hydroxide:lead oxide:PEG & $90: 3: 1: 6$ \\
\hline $\mathrm{C} 3$ & commercial ZnO:calcium hydroxide:lead oxide:PEG & $84: 3: 1: 12$ \\
\hline $\mathrm{C} 4$ & commercial ZnO:calcium hydroxide:lead oxide:PVA & $93: 3: 1: 3$ \\
\hline C5 & commercial ZnO:calcium hydroxide:lead oxide:PVA & $90: 3: 1: 6$ \\
\hline C6 & commercial ZnO:calcium hydroxide:lead oxide:PVA & $84: 3: 1: 12$ \\
\hline
\end{tabular}

2.7 $\mathrm{M} \mathrm{KOH}$ solution was used as an electrolyte in experimental study. For cell testing, zinc electrodes and nickel electrodes were placed in a beaker filled with 2.7 M KOH electrolyte. Nickel electrodes as an anode are used in commercial NiMH batteries with 2050 mAh capacity in this study. No further treatment or process was applied. Nickel electrode capacity was kept twice the theoretical capacity required for testing by connecting multiple nickel electrodes in parallel.

\section{Electrochemical tests}

The charge/discharge tests were performed using two DC power supplies (RXN 305D) which work either current or voltage limited. All tests were performed at room temperature. Initial charging of the cells was performed at a constant voltage of $2.4 \mathrm{~V}$. Discharge tests were applied by attaching a $10-\Omega$ load to cells. Zinc electrodes after charge-discharge cycles were dried at $30^{\circ} \mathrm{C}$ under vacuum for evaluation of microstructure during battery operation. 


\section{RESULTS AND DISCUSSION}

\section{The characterization of zinc oxide powder}

The characterization of zinc oxide powders which were necessary for the production the zinc electrode were detail given in our previous work [32]. When briefly referring to the results, the XRD analysis showed that the existence of only $\mathrm{ZnO}$ in synthesized powders was confirmed, and no peaks related to $\mathrm{Zn}(\mathrm{OH})_{2}$ was observed [32]. Based on the results of SEM, it was found that the commercial ZnO powder had greater crystallinity compared to synthesized ZnO powders. Beside this, $\mathrm{ZnO}$ powder synthesized from $\mathrm{ZnCl}_{2}$ had a homogeneous distribution of spherical particles while $\mathrm{ZnO}$ powder synthesized from $\mathrm{Zn}\left(\mathrm{NO}_{3}\right)_{2} .6 \mathrm{H}_{2} \mathrm{O}$ showed different morphologies with plate-like structures mixed with need-like particles. Also, the commercial ZnO showed a wide range of particle size distribution with most of the particles having needle-like shapes as well as having tripod and nanorod shapes [32].

\section{XRD patterns analysis of zinc electrodes}

In order to confirm initial findings related to morphology of the electrode before its first charge, after first charge and first discharge, XRD analysis is performed on each zinc electrode containing different $\mathrm{ZnO}$ powders (commercial $\mathrm{ZnO}$ powder, $\mathrm{ZnO}$ powder synthesized from both $\mathrm{ZnCl}_{2}$ and $\left.\mathrm{Zn}\left(\mathrm{NO}_{3}\right)_{2} .6 \mathrm{H}_{2} \mathrm{O}\right)$ and $3 \mathrm{wt} . \%$ PEG as a binder, as shown in Figure 1. The XRD patterns show that the content of zinc oxide is dominant for each zinc electrode (JCPDS-2 79-2205, JCPDS-2 240222). Compared all the XRD patterns, the course of the baseline indicated that no-impurity phase is observed.

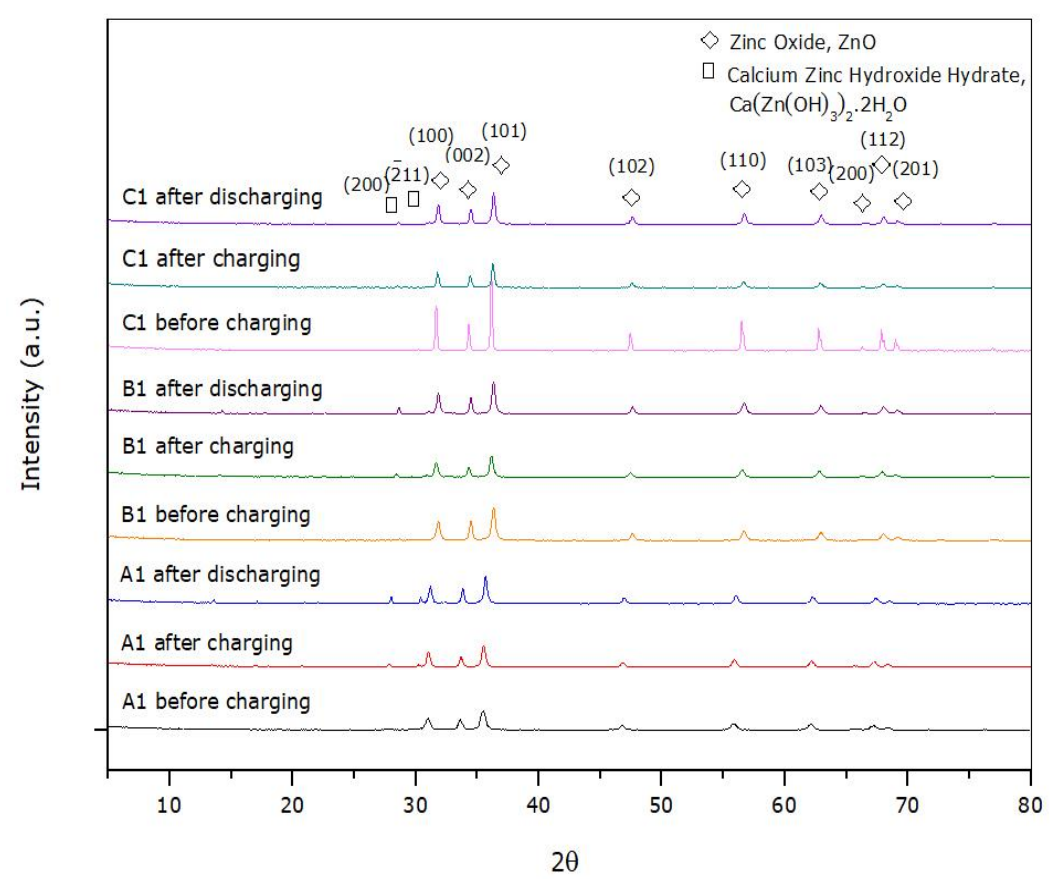

Figure 1: XRD spectra of each zinc electrode before charging, after charging and after discharging. 
XRD spectra of all zinc electrodes containing binders, either PEG or PVA, with different concentrations are presented in Figure 2. The XRD patterns show that zinc oxide was dominant phase for each zinc electrode after three charge/discharge cycles (JCPDS-2 79-2205, JCPDS-2 24-0222). Figure $2 a$ shows XRD spectra of zinc electrodes containing ZnO synthesized from $\mathrm{ZnCl}_{2}$. Based on XRD spectra of samples $\mathrm{A}$, there are some weak peaks of calcium zincate (CaZn) for sample $A 2$ and $A 4$. The XRD spectra of zinc electrodes containing ZnO synthesized from $\mathrm{Zn}\left(\mathrm{NO}_{3}\right)_{2} .6 \mathrm{H}_{2} \mathrm{O}$, as shown in Figure $2 \mathrm{~b}$. Similar to samples $\mathrm{A}$, the weak peaks of calcium zincate are detected in all samples $B$. It can be concluded that is no difference between all zinc electrodes after third discharge and electrode paste before first charge, and the result corresponds to previous report in the literature [32].

\section{(a)}

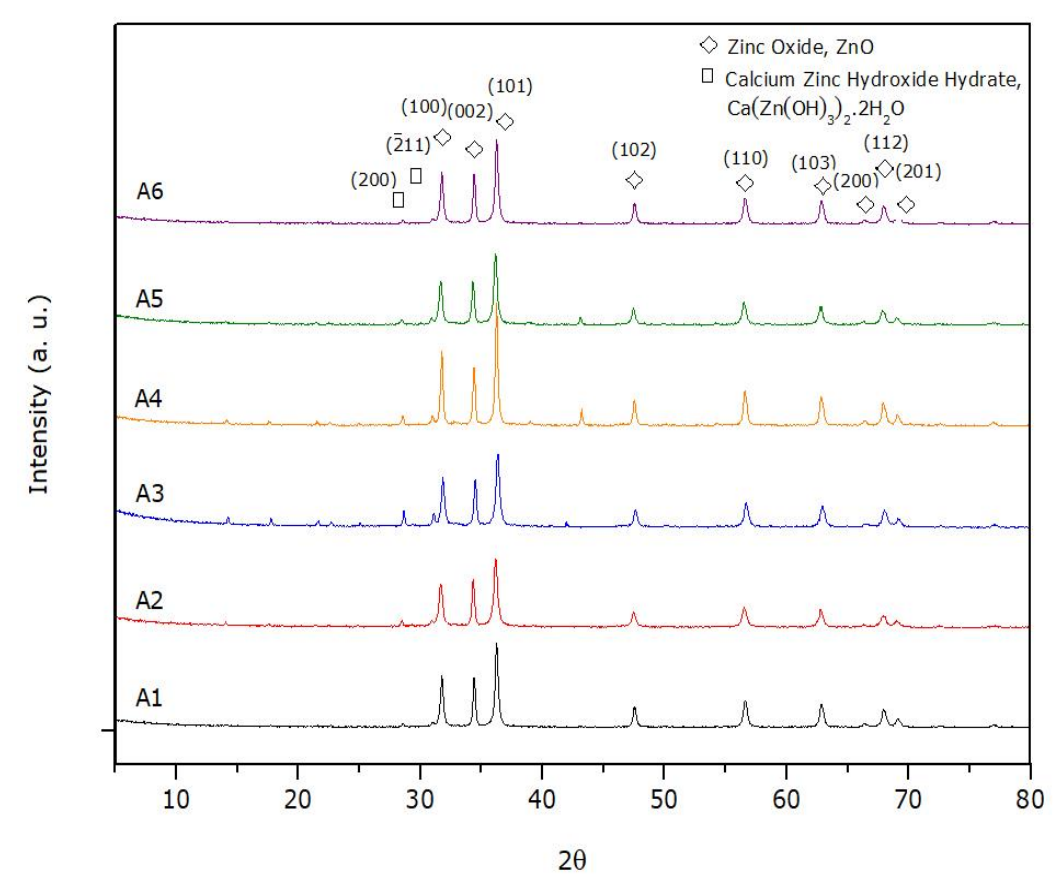

(b)

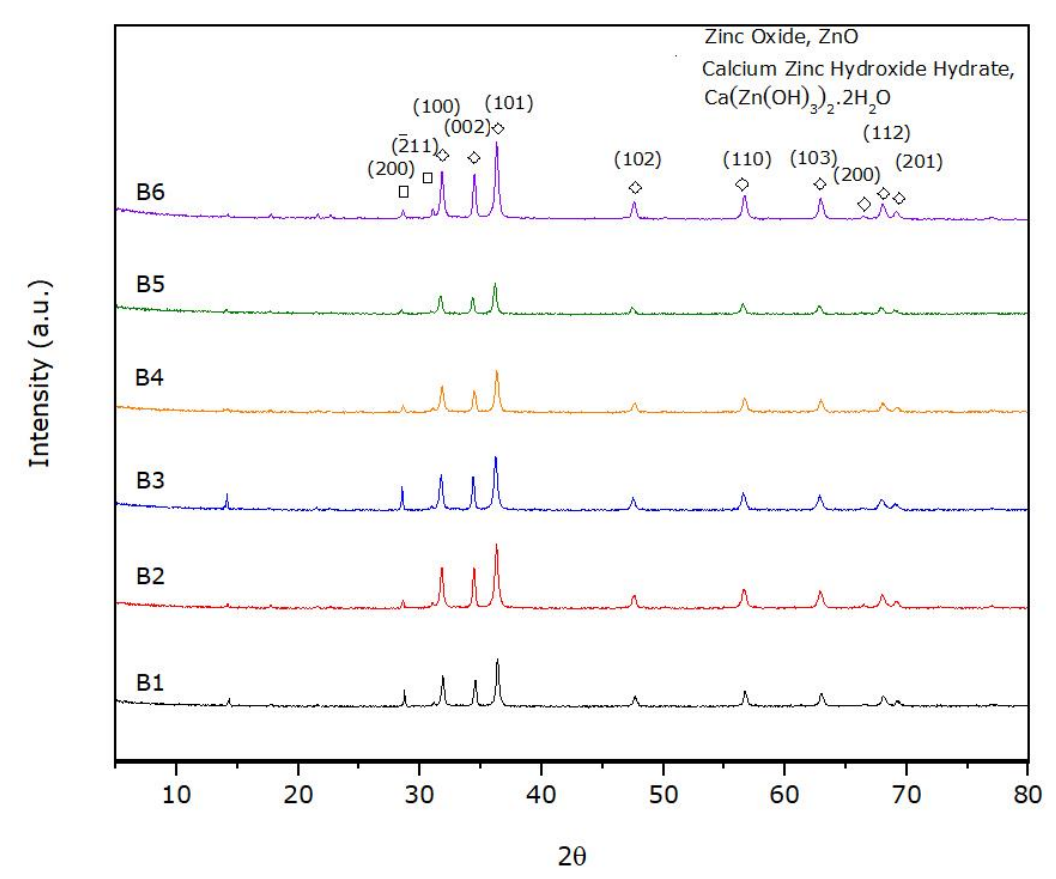


(c)

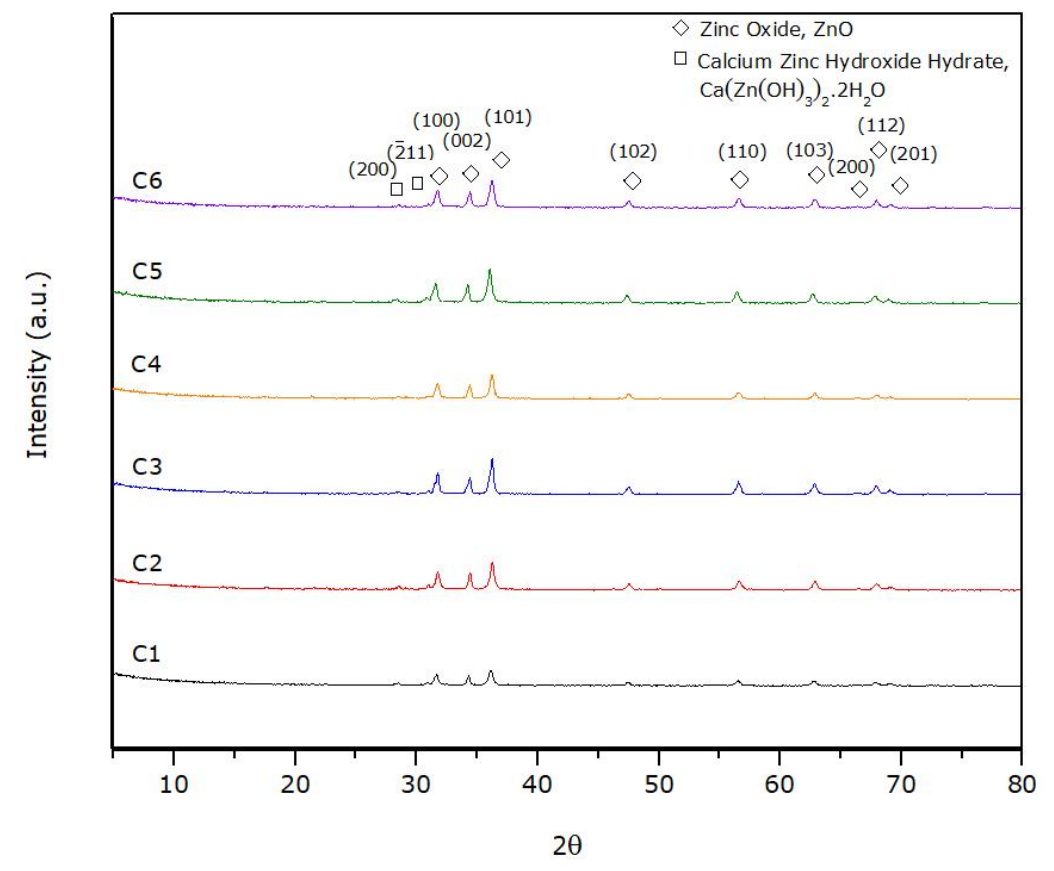

Figure 2: XRD spectra of zinc electrode for (a) $\mathrm{ZnO}$ synthesized $\mathrm{ZnCl}_{2}$, (b) $\mathrm{ZnO}$ synthesized $\mathrm{Zn}\left(\mathrm{NO}_{3}\right)_{2} .6 \mathrm{H}_{2} \mathrm{O}$, (c) commercial $\mathrm{ZnO}$.

\section{Morphology evolution of zinc electrodes}

The morphology evolution process of zinc electrode prepared using zinc oxide powder synthesized from $\mathrm{ZnCl}_{2}$ and $3 \mathrm{wt}$.\% PEG as a binder before charge, after first charge and first discharge are shown in Figure 3. The microstructure and surface morphology of the paste zinc electrode is shown in Figure 3a. The SEM image of zinc electrode after first charge is shown in Figure $3 \mathrm{~b}$. Compared to Figure $3 \mathrm{a}$ and Figure $3 \mathrm{~b}$, ZnO nanospheres were mostly replaced spindlelike structures, and most of the ZnO crystals were converted into zinc. However, detailed SEM analysis at different locations of the sample also reveals that first charging of these zinc electrode was not performed fully and there were some ZnO particles, which were not converted into metallic zinc. Figure $3 c$ displays the morphology of the same zinc electrode after first discharge. It was observed that regardless of the initial morphology, the electrode showed morphologies almost completely erasing the memory of initial structure even after the first charging procedure.

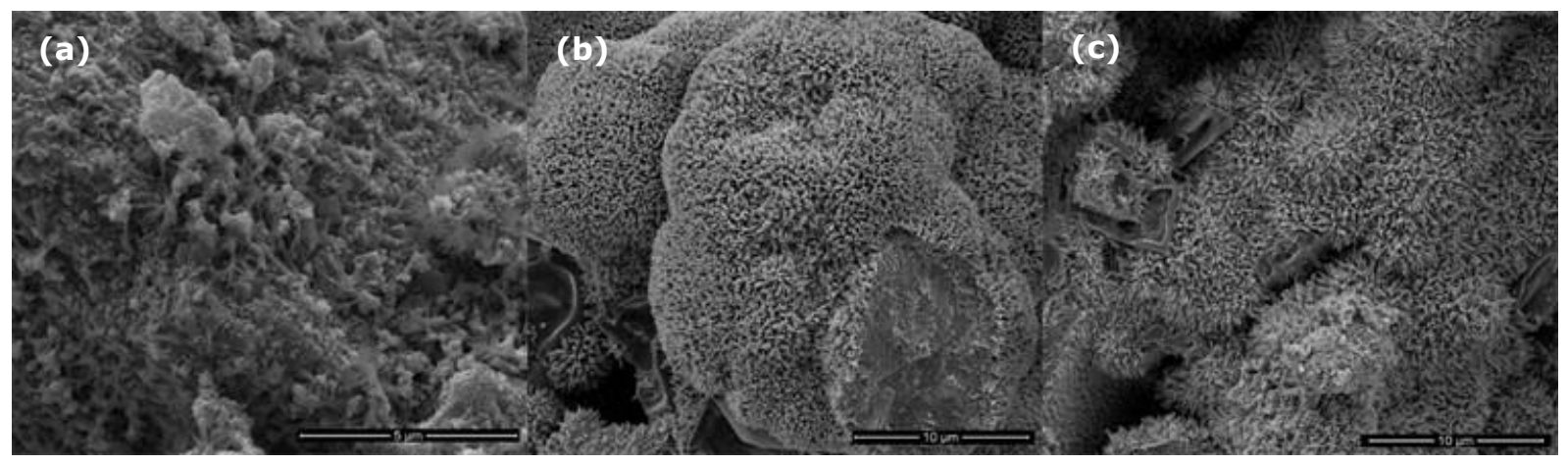

Figure 3: Morphology evolution of zinc electrodes for sample A1 (a) before charge, (b) after first charge, (c) after first discharge. 
The microstructure evolution process of each zinc electrode containing ZnO synthesized from $\mathrm{ZnCl}_{2}$ and selected binders (PEG or PVA) with varying loading from $3 \mathrm{wt} . \%$ to $12 \mathrm{wt} . \%$ is shown in Figure 4. Compared to the initial morphology of $\mathrm{ZnO}$ as seen in Figure 4a, $\mathrm{ZnO}$ nanospheres were converted to spindle-like structures. Large zinc crystals (flower like growth) with high aspect ratios were observed. However, these large crystals were also accompanied by smaller dendritic structures. From Figure $4 a-f$, it can be seen that the microstructure and surface morphology of each zinc electrode prepared using $\mathrm{ZnO}$ synthesized from $\mathrm{ZnCl}_{2}$ did not essentially change with the type of binder, PEG and PVA. With increasing of loading of binder, as shown in Figure 4a-f, the prismatic crystal growth of $\mathrm{ZnO}$ slightly decreases.

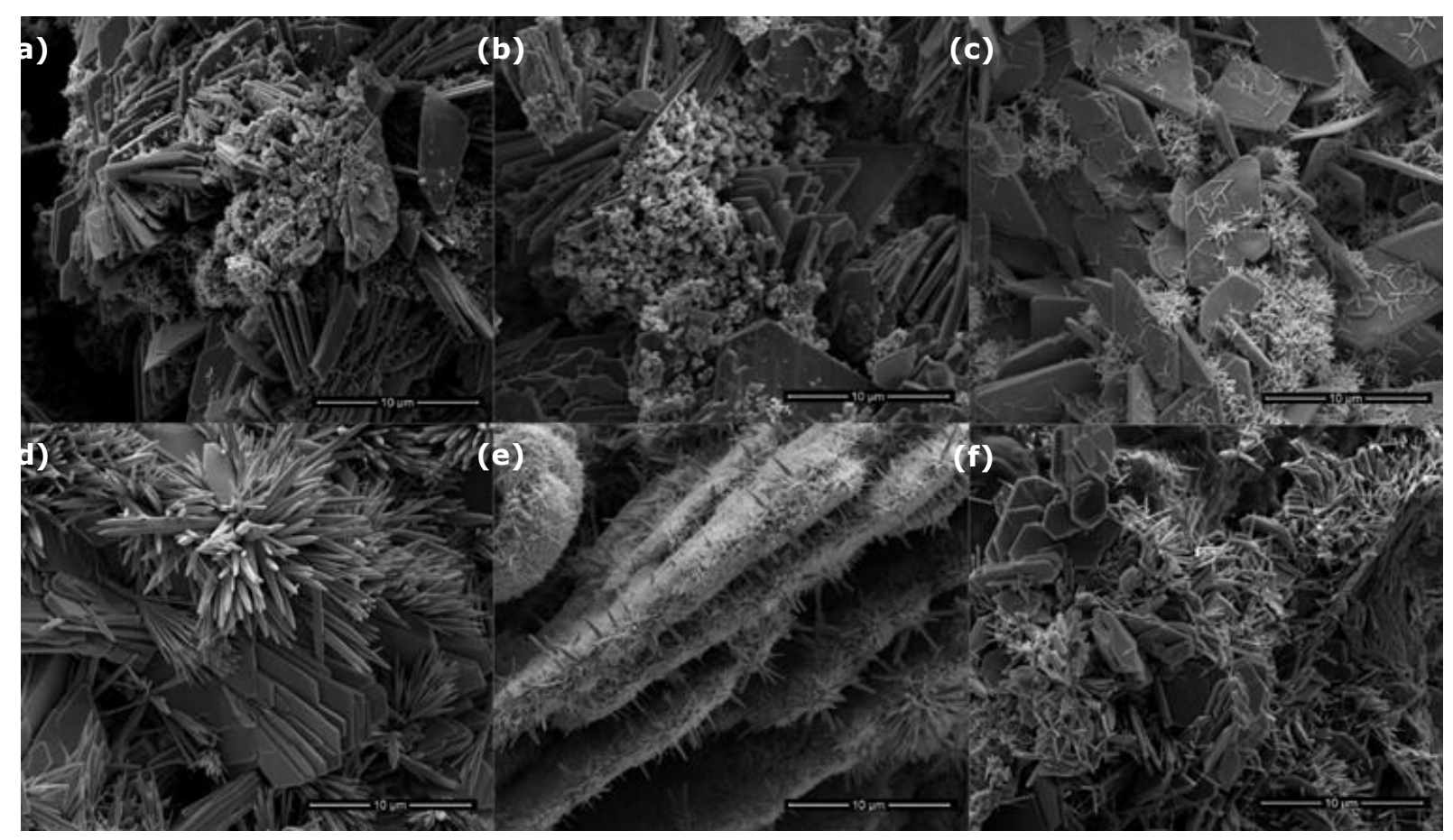

Figure 4: Morphology evolution of zinc electrodes for samples (a) A1, (b) A2, (c) A3, (d) A4, (e) A5, (f) A6.

The microstructure evolution process of zinc electrode prepared using $\mathrm{ZnO}$ powder synthesized from $\mathrm{Zn}\left(\mathrm{NO}_{3}\right)_{2} .6 \mathrm{H}_{2} \mathrm{O}$ and $3 \mathrm{wt} . \%$ PEG before charge, after first charge and first discharge is shown in Figure 5. After charge/discharge cycle, the morphology of zinc electrode was found to be different than its initial morphology in terms of particle size and shape. Similarly, the morphology of zinc electrode shows spindle-like structures, and most of the ZnO crystals were converted into zinc after first charge, as seen in Figure $5 \mathrm{~b}$ and Figure $5 \mathrm{c}$. 


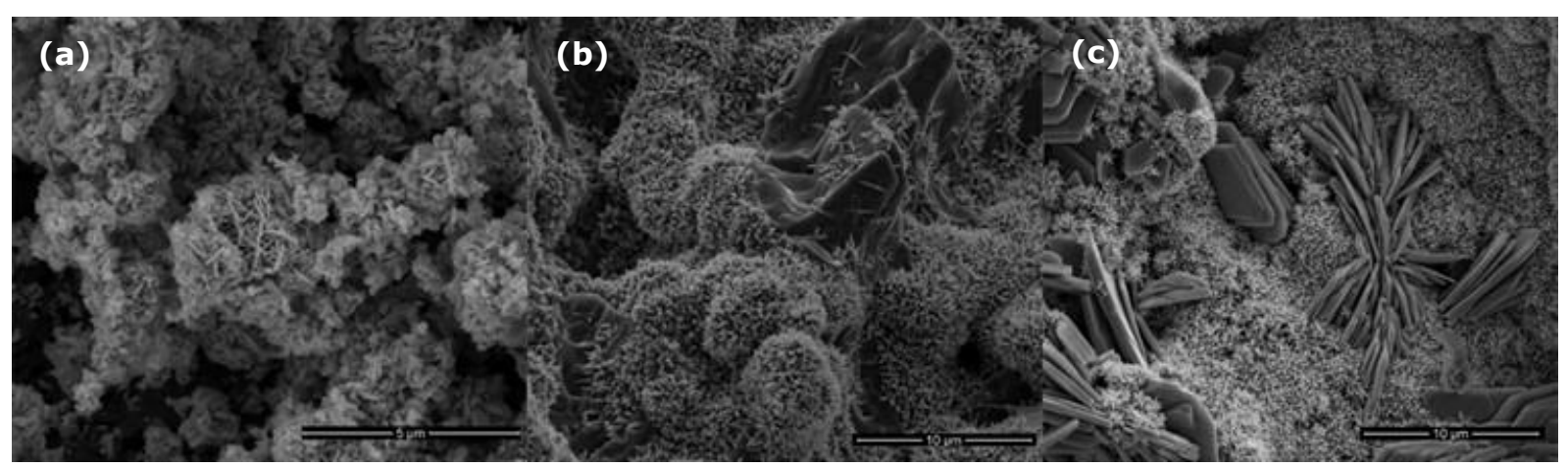

Figure 5: Morphology evolution of zinc electrodes for sample B1 (a) before charge, (b) after first charge, (c) after first discharge.

Figure 6 shows the morphology of zinc electrode prepared using ZnO synthesized from $\mathrm{Zn}\left(\mathrm{NO}_{3}\right)_{2} .6 \mathrm{H}_{2} \mathrm{O}$ and different binders with various concentrations (3, 6 and $12 \mathrm{wt} . \%$ ) after charge/discharge cycling. The plate-like structure of this kind of zinc electrode was replaced by spindle-like structures. It was observed that the electrodes showed similar morphologies almost completely erasing the memory of initial structure after the third discharging procedure. Based on SEM images, similar morphology change was observed when the loading of binder varied from 3 wt. \% to 12 wt.\% for both PEG and PVA as binders for zinc electrodes.

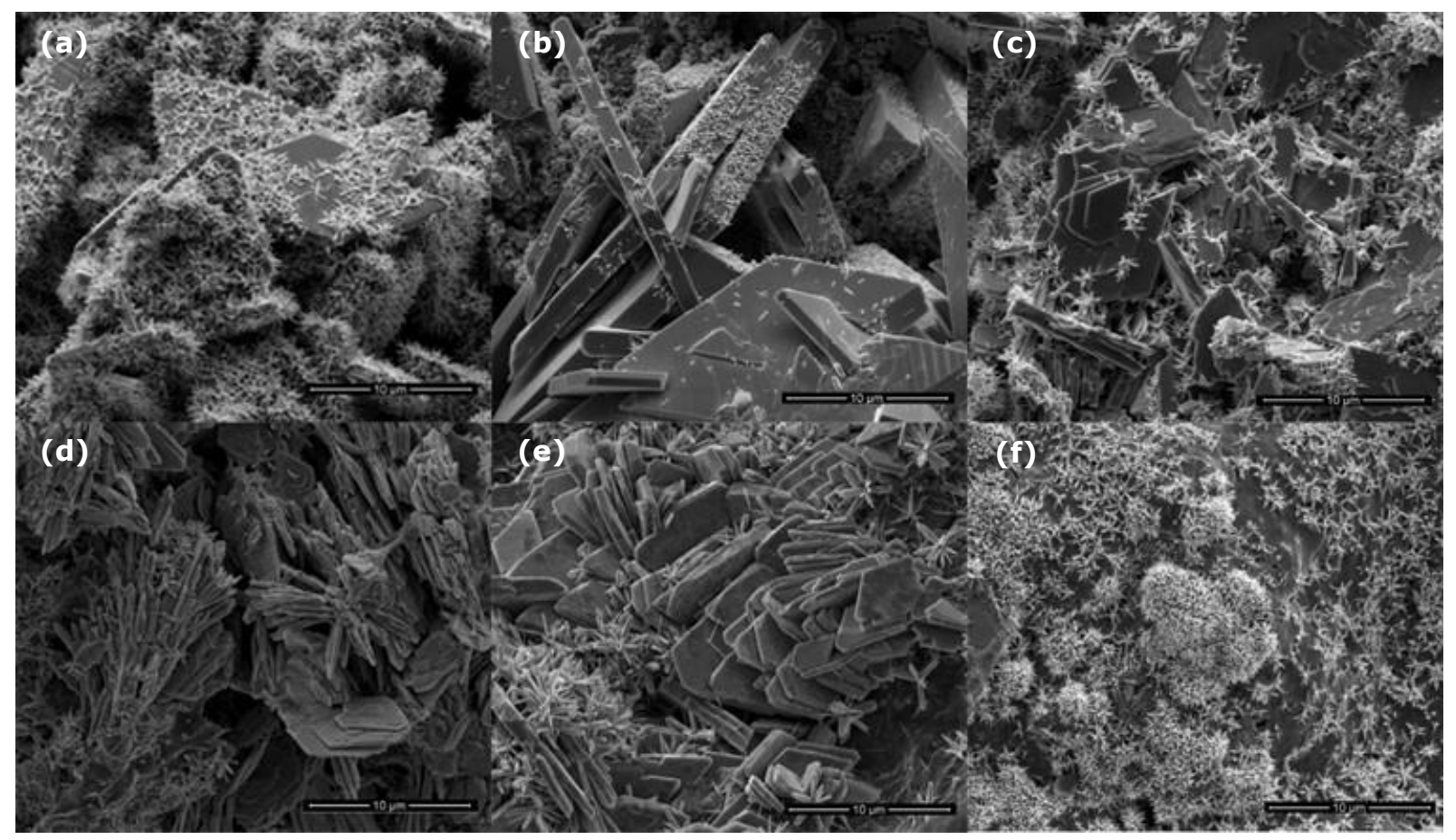

Figure 6: Morphology evolution of zinc electrodes for samples (a) B1, (b) B2, (c) B3, (d) B4, (e) B5, (f) B6.

The morphology evolution process of zinc electrode prepared using commercial ZnO powder and 3 wt.\% PEG as a binder before charge, after first charge and first discharge are shown in Figure 7. The microstructure and surface morphology of the paste used for zinc electrode is shown in Figure 7a. After first charge/discharge process, the hexagonal structure of $\mathrm{ZnO}$ almost 
disappeared and turned into dendritic form, as seen in Figure 7b and Figure 7c. However, detailed SEM analysis at different locations of the zinc electrode also reveals that first charging of this kind of zinc electrode was not performed fully and there were some $\mathrm{ZnO}$ particles which were not converted into metallic zinc.

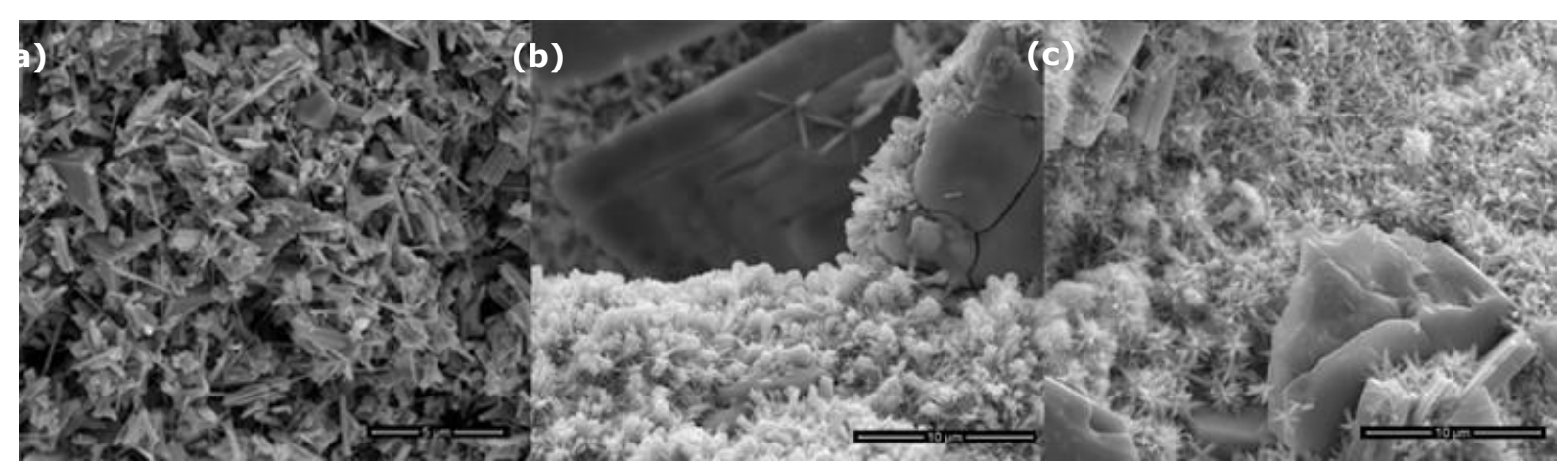

Figure 7: Morphology evolution of zinc electrodes for sample $\mathrm{C} 1$ (a) before charge, (b) after first charge, (c) after first discharge.

The morphology structures of zinc electrodes prepared using commercial ZnO powder and binder either PEG or PVA with various concentrations are displayed in Figure 8. The change in surface morphology of each zinc electrode related to the deposition of zinc after third discharge is same, as illustrated in Figure 8a-f. Compared to the initial morphology of zinc electrode as seen in Figure $7 a$, the morphology of hexagonal structure of zinc electrode changed, and replaced with zinc particles in acicular form, namely the dendritic zinc. From Figure 8a-f, it can be seen that the structure of each ZnO did not essentially change with the type of binder, PEG and PVA. With increasing of loading of binders, as shown in Figure 8a-f, the prismatic crystal growth of ZnO slightly decreases. Based on SEM analysis of zinc electrode prepared using commercial ZnO powder, the effect of binder type and binder loading seems to be minimal. 


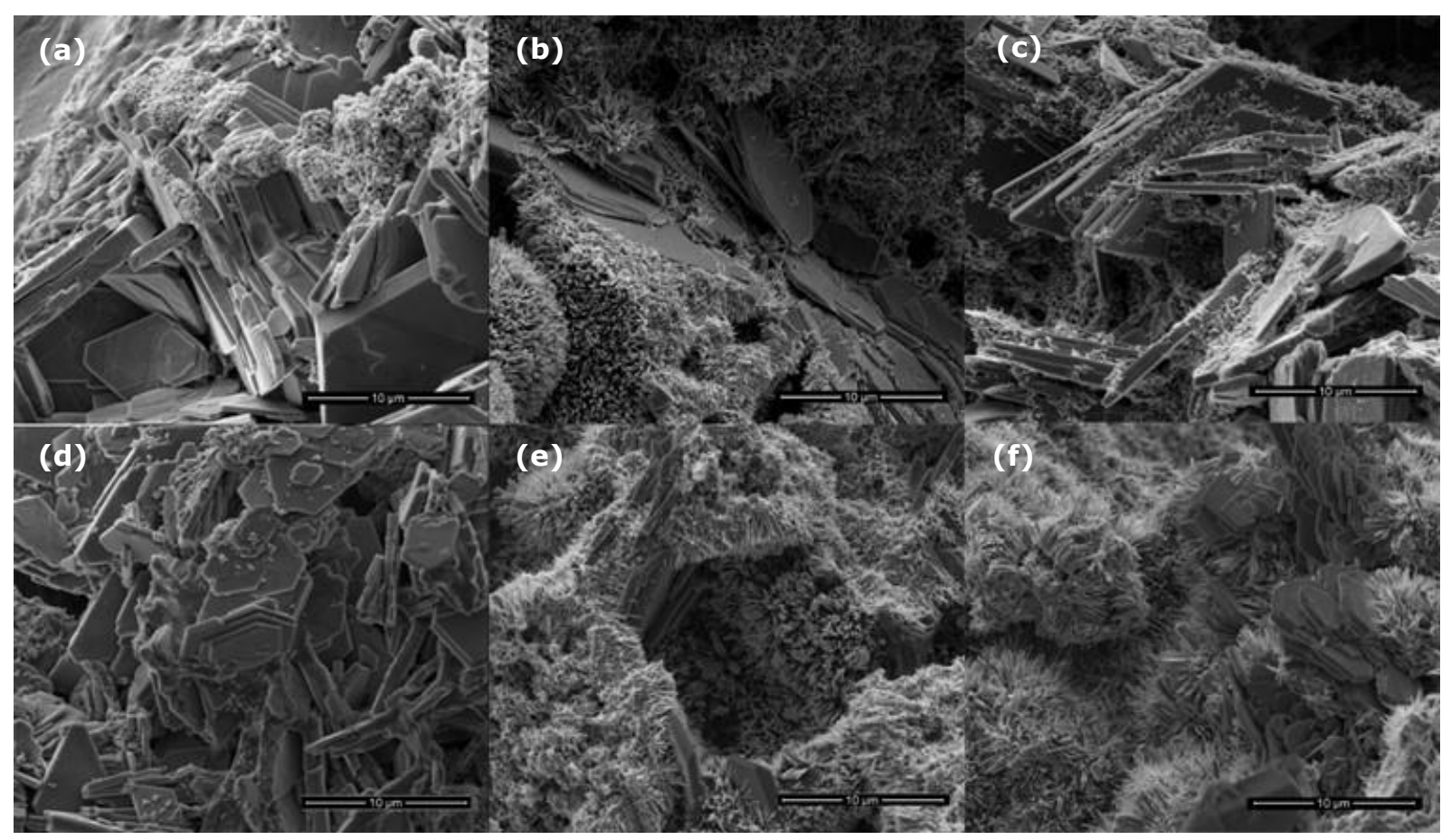

Figure 8: Morphology evolution of zinc electrodes for samples (a) C1, (b) C2, (c) C3, (d) C4, (e) C5, (f) C6.

\section{Electrochemical performance of the zinc electrode}

The electrochemical characteristics of pouch cell NiZn batteries were evaluated by charging and discharging batteries until complete battery failure. Initial charging of NiZn batteries were carried out at constant $2.4 \mathrm{~V}$ and room temperature. All NiZn batteries were charged until the current of battery reached to about $0.175 \mathrm{~A}$. Fully charged batteries were discharged using a 10-Ohm resistance as load until battery potential reached to about $0.45 \mathrm{~V}$. All charge-discharge tests were performed under the same conditions. The typical discharge curves of NiZn batteries tested at the third cycle are displayed in Figure 9a-c. Since electrolyte concentration, nickel electrode capacity and all other experimental parameters were the same, voltage-capacity curves give valuable information about zinc electrode electrochemical behavior. Compared to cells with zinc electrodes prepared by $\mathrm{ZnO}$ powders synthesized from $\mathrm{ZnCl} 2$ and $\mathrm{Zn}\left(\mathrm{NO}_{3}\right)_{2} .6 \mathrm{H}_{2} \mathrm{O}$, cells with electrodes prepared with commercial ZnO powder shows consistent discharge behavior and higher capacity.

In comparison with PVA-based zinc electrodes, the proposed PEG-based zinc electrode dramatically shows a higher discharge capacity at the same conditions. The discharge curves of NiZn batteries containing $\mathrm{ZnO}$ powder synthesized from $\mathrm{ZnCl}_{2}$ and binder, PEG and PVA, with different concentrations are shown in Figure 9a. These kinds of batteries with PVA as a binder exhibit lower discharge capacity than those with PEG. The zinc electrode containing ZnO powder synthesized from $\mathrm{ZnCl}_{2}$ and 6 wt.\% PEG shows better specific capacity of $255 \mathrm{mAhg}^{-1}$ than the other loading of PEG. Similarly, the specific capacity of zinc electrode containing same ZnO powder and 6 wt.\% PVA (155 mAhg ${ }^{-1}$ ) is more than the other loading of PVA. Furthermore, the 
discharge plateaus of the batteries with PEG are smoother than those with PVA. The discharge curves of zinc electrode containing $\mathrm{ZnO}$ powder synthesized from $\mathrm{Zn}\left(\mathrm{NO}_{3}\right)_{2} .6 \mathrm{H}_{2} \mathrm{O}$ with different PEG and PVA concentrations are shown in Figure 9b. These kinds of batteries with PVA exhibit lower discharge capacity than with PEG. The zinc electrode containing the same synthesized ZnO powder and $12 \mathrm{wt}$ \% PEG reaches higher discharge capacity of $275 \mathrm{mAhg}^{-1}$ compared to those with other PEG concentrations, whereas these kind of zinc electrode with 3 wt.\% PVA shows higher specific capacity of $180 \mathrm{mAhg}^{-1}$ than those with other PVA concentrations. Zinc electrodes using commercial ZnO powder and PEG as a binder show the high discharge plateu, which means high output energy and power, and average discharge capacity of $311 \mathrm{mAg}^{-1}$, as illustrated in Figure 9c.

The ZnO morphology and selected binders definitely have an impact on the electrochemical performance of the batteries in terms of high discharge capacity.

(a)

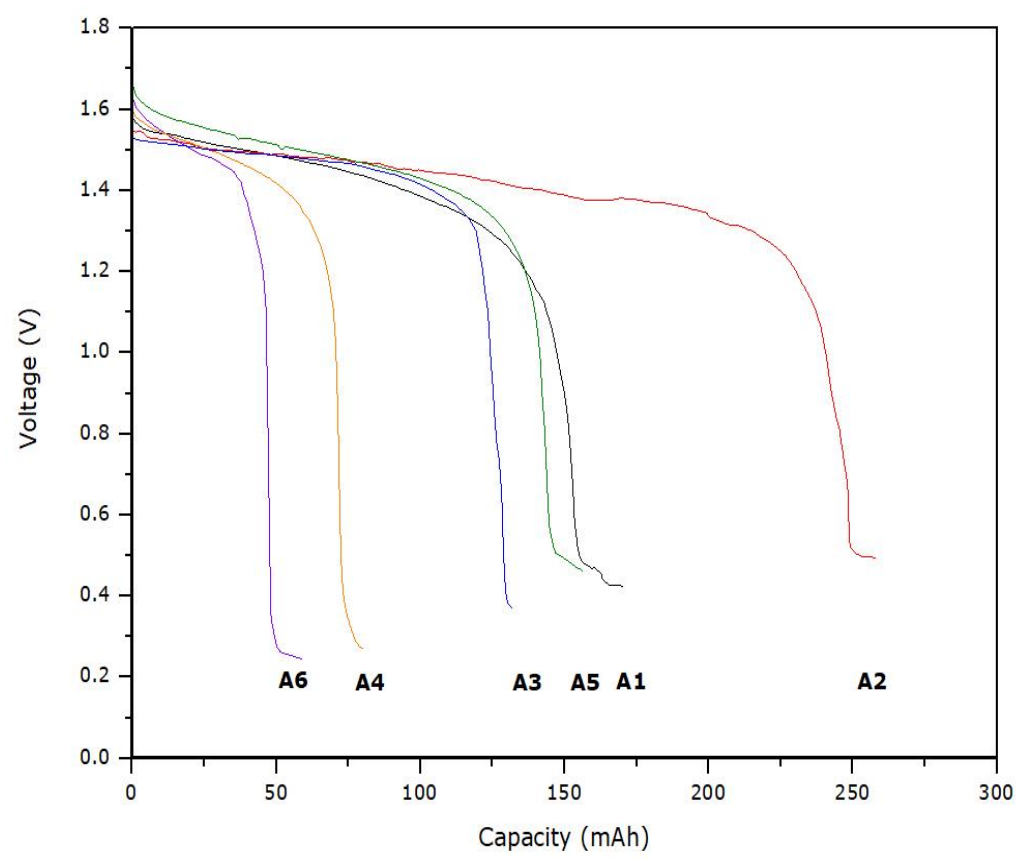


(b)

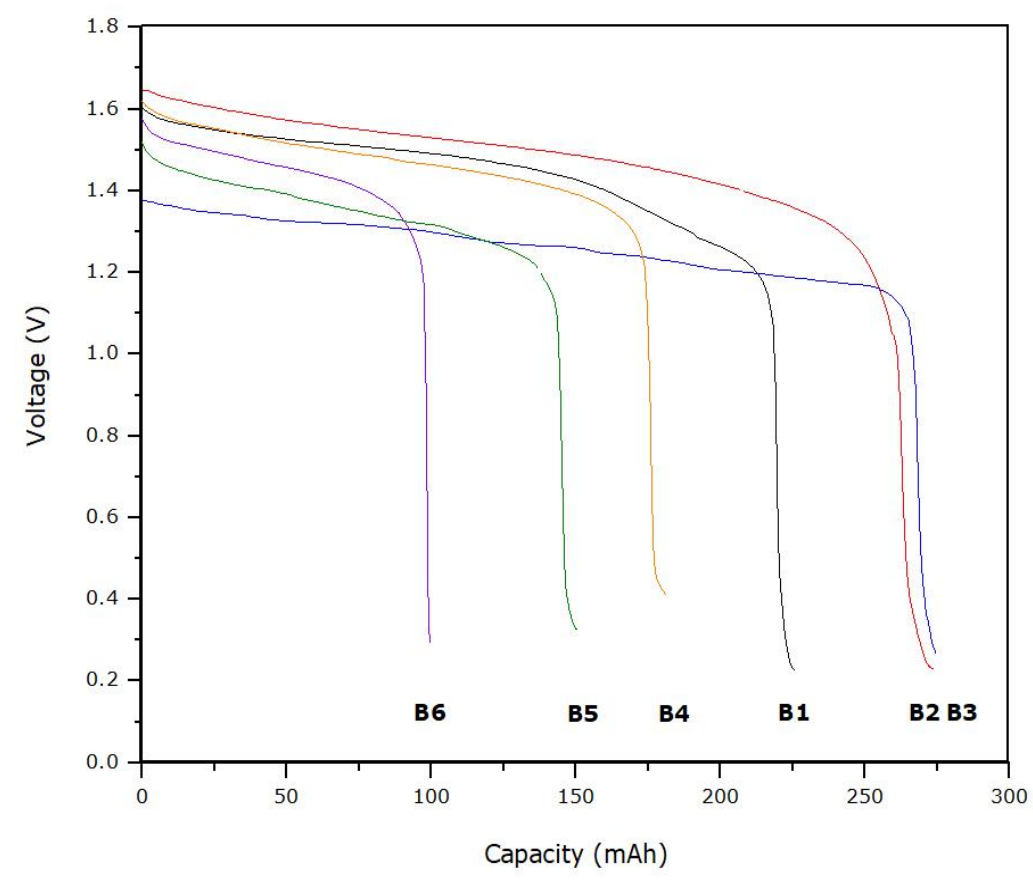

(c)

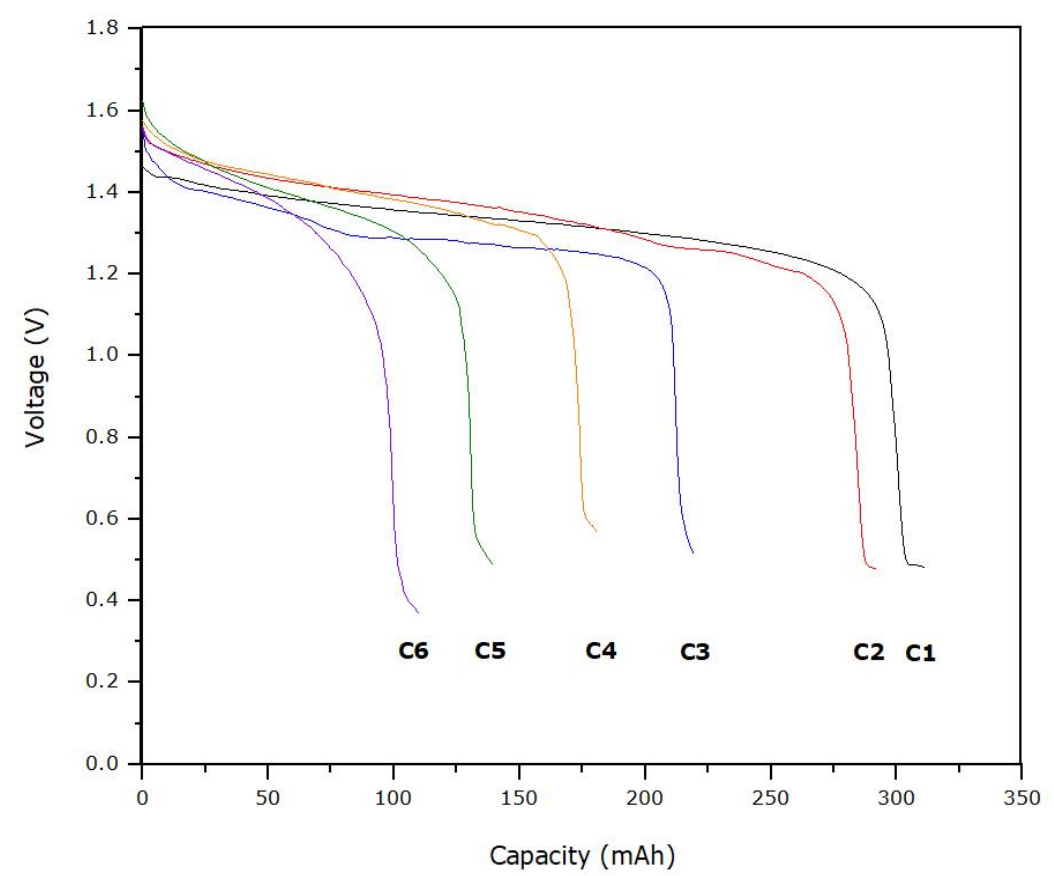

Figure 9: The discharge curves of $\mathrm{NiZn}$ batteries for (a) $\mathrm{ZnO}$ synthesized $\mathrm{ZnCl}_{2}$, (b) $\mathrm{ZnO}$ synthesized $\mathrm{Zn}\left(\mathrm{NO}_{3}\right)_{2} .6 \mathrm{H}_{2} \mathrm{O}$, (c) commercial $\mathrm{ZnO}$.

Based on the results of discharge capacity for all NiZn batteries, initial morphology of zinc electrode as well as type and loading of binder material plays a role in battery performance. Additionally, electrode surface area available for electrochemical reactions causes the change in discharge performance of battery. The increase in the surface area of zinc electrode exhibits the increase in materials utilization and power density and the reduction of passivation at high discharge rates in NiZn batteries [23, 32]. High surface area of zinc electrode can improve battery performance due to short ion transport length for both electron and zinc ion transport, 
high electrode/electrolyte contact area and easy charge transfer reaction on electrodeelectrolyte interface [33-36].

The test setup was based on pouch cells and liquid $\mathrm{KOH}$ electrolyte. This setup is far from the ideal battery configuration (AA size or prismatic almost dry cell) however; it still provides valuable information regarding to zinc electrode behavior. Due to high internal resistivity of the cells used this study, voltage and current values measured during testing are far from commercial NiZn batteries. On the other hand, isolation of zinc electrode from nickel electrode in this setup by a large amount of potassium hydroxide solution prevented passivation of zinc electrode at high discharge rates.

\section{CONCLUSION}

In this study, the influence of the binder on the electrochemical behavior of zinc electrode for pouch cell NiZn battery was investigated. By comparison with the types and loading of binders in zinc electrodes, the electrochemical properties of the electrodes were evaluated by charge/discharge cycling test. Clearly, binder loading and binder type have an effect on electrode discharge capacity. Based on these findings related to all zinc electrodes, the following conclusions can briefly be made:

- As investigated the results of zinc electrode including commercial ZnO powder, the PEG loading of $3 \mathrm{wt}$ \% exhibits the maximum discharge capacity of $311 \mathrm{mAg}^{-1}$. The specific discharge capacity of these zinc electrodes decreases gradually accompanied with the increasing loading of PEG. Additionally, the discharge capability of PEG as a binder shows more efficient than that of PVA. Similar to result of PEG behavior, the increase in the PVA loading leads to reduce the discharge capacity of this kind of zinc electrodes.

- Among all results of zinc electrode containing ZnO powder synthesized from $\mathrm{Zn}\left(\mathrm{NO}_{3}\right)_{2} .6 \mathrm{H}_{2} \mathrm{O}$ as a precursor, the PEG loading of $12 \mathrm{wt}$ \% shows the highest specific discharge capacity of $275 \mathrm{mAhg}^{-1}$. At the same time, the discharge capacity of this kind of zinc electrode is approximately the same as that when using a PEG loading of $6 \mathrm{wt}$.\% and $12 \mathrm{wt} . \%$. These kinds of zinc electrodes with PVA as a binder exhibit lower discharge capacity than those with PEG. The specific discharge capacity of these zinc electrodes decreases with increasing PVA loading.

- Compared to the results of zinc electrode using commercial $\mathrm{ZnO}$ powder and synthesized $\mathrm{ZnO}$ powder from $\mathrm{Zn}\left(\mathrm{NO}_{3}\right)_{2} .6 \mathrm{H}_{2} \mathrm{O}$ as a precursor, the discharge capacity of zinc electrode using synthesized $\mathrm{ZnO}$ powder from $\mathrm{ZnCl}_{2}$ displays different behavior. For discharge capacity, zinc electrode using synthesized $\mathrm{ZnO}$ powder from $\mathrm{ZnCl}_{2}$ and 6 wt.\% of PEG as a binder exhibits the highest capacity of $255 \mathrm{mAhg}^{-1}$, however, other loading of PEG (3 and $12 \mathrm{wt} . \%$ ) for this kind of zinc electrode give dramatically lower discharge capacity. It could be said that PEG as a binder used in zinc electrode with synthesized $\mathrm{ZnO}$ powder from $\mathrm{ZnCl}_{2}$ performs better performance than PVA. The discharge capacity delivered by 
this kind of zinc electrode with 6 wt.\% PVA $\left(157 \mathrm{mAhg}^{-1}\right)$ is more than those with other PVA loading ( 3 and 12 wt. \%).

It was concluded that the specific discharge capacity of zinc electrode for pouch cell NiZn battery is not only dependent on the binder loading and type, but also the initial morphology of ZnO powder.

\section{ACKNOWLEDGEMENTS}

The authors are thankful Dr. Ogan Ocali and Prof. Dr. Muhsin Çiftçioğlu for their valuable advice, comments and discussions. We thank Ocali A.S. for financial support to perform this work.

\section{REFERENCES}

1. Huang $H$, Zhang L, Zhang WK, Gan YP, Shao H. Preparation and electrochemical properties of $\mathrm{ZnO} /$ conductive-ceramic nanocomposite as anode material for $\mathrm{Ni} / \mathrm{Zn}$ rechargeable battery. J Power Sources. 2008 Oct; 184:663-7. DOI: 10.1016/j.jpowsour.2008.01.004.

2. Cheng J, Zhang L, Yang YS, Wen YH, Cao GP, Wang XD. Preliminary study of single flow zinc-nickel battery. Electrochem Commun. 2007 Nov; 9:2639-42. DOI: 10.1016/j.elecom.2007.08.016.

3. Zhang XG, editor. Corrosion and Electrochemistry of Zinc. Springer; 1996. ISBN: 1475798784.

4. Huggins RA, editor. Advanced Batteries. Springer; 2009. ISBN: 9780387764238.

5. Acton QA, editor. Sulfur Acids-Advances in Research and Application: 2013 Edition. Scholarly Editions; 2013. ISBN: 978-1-481-69276-2.

6. Müeller S, Holzer F, Haas O. Optimized zinc electrode for the rechargeable zinc-air battery. J Appl Electrochem. 1998 Sept; 28: 895-8. DOI: 10.1023/A:1003464011815.

7. Yuan YF, Tu JP, Wu HM, Li Y, Shi DQ, Zhao XB. Effect of ZnO nanomaterials associated with $\mathrm{Ca}(\mathrm{OH}) 2$ as anode material for $\mathrm{Ni}-\mathrm{Zn}$ batteries. J Power Sources. 2006 Sept; 159:357-60. DOI: 10.1016/j.jpowsour.2006.04.010.

8. Shivkumar R, Paruthimal Kalaignan G, Vasudevan T. Studies with porous zinc electrodes with additives for secondary alkaline batteries. J Power Sources. 1998 Sept; 75:90-100. DOI: 10.1016/S03787753(98)00096-2.

9. McBreen J, Gannon E. The electrochemistry of metal oxide additives in pasted zinc electrodes. Electrochim Acta. 1981 Oct; 26 1439-46. DOI: 10.1016/0013-4686(81)90015-3. 
10. Shivkumar R, Kalaignan GP, Vasudevan T. Effect of additives on zinc electrodes in alkaline battery systems. J Power Sources. 1995 May; 55:53-62. DOI: 10.1016/0378-7753(94)02170-8.

11. Adler TC, McLarnon FR, Cairns EJ. Low-zinc-solubility electrolytes for use in zinc/nickel oxide cells. J Electrochem Soc. 1993 Oct; 140:289-94. DOI: 10.1149/1.2221039.

12. Iwakura $\mathrm{C}$, Murakami $\mathrm{H}$, Nohara S, Furukawa N, Inoue $\mathrm{H}$. Charge-discharge characteristics of nickel/zinc battery with polymer hydrogel electrolyte. J Power Sources. 2005 Dec; 152, 291-294. DOI: 10.1016/j.jpowsour.2005.03.175.

13. Yuan YF, Tu JP, Wu HM, Li Y, Shi DQ. Size and morphology effects of ZnO anode nanomaterials for Zn/Ni secondary batteries. Nanotechnology. 2005 Apr; 16:803-8. DOI: 10.1088/0957-4484/16/6/031.

14. Yang JL, Yuan YF, Wu HM, Li Y, Chen YB, Guo SY. Preparation and electrochemical performances of ZnO nanowires as anode materials for Ni/Zn secondary battery. Electrochim Acta. 2010 Sept; 55:7050-4. DOI: $10.1016 /$ j.electacta.2010.06.075.

15. Perez MG, O'Keefe MJ, O'Keefe T, Ludlow D. Chemical and morphological analyses of zinc powders for alkaline batteries. J Appl Electrochem. 2006 Feb; 37:225-31. DOI: 10.1007/s10800-006-9239-3.

16. Yuan YF, Tu JP, Wu HM, Li Y, Shi DQ, Zhao XB. Effect of ZnO nanomaterials associated with $\mathrm{Ca}(\mathrm{OH})_{2}$ as anodematerial for $\mathrm{Ni}-\mathrm{Zn}$ batteries. J Power Sources. $2006 \mathrm{Sept}$; 159:357-60. DOI: 10.1016/j.jpowsour.2006.04.010.

17. Yang CC, Chien WC, Wang CL, Wu CY. Study the effect of conductive fillers on a secondary Zn electrode based on ball-milled $\mathrm{ZnO}$ and $\mathrm{Ca}(\mathrm{OH})_{2}$ mixture powders. J Power Sources. 2007; 172:435-45. DOI: 10.1016/j.jpowsour.2007.07.053.

18. Yuan YF, Yu LQ, Wu HM, Yang JL, Chen YB, Guo YB, Tu JP. Electrochemical performances of Bi based compound film-coated ZnOas anodic materials of Ni-Zn secondary batteries. Electrochim Acta. 2011 Apr; 56:4378-83. DOI: 10.1016.j.electacta.2011.01.006.

19. Shivkumar R, Kalaignan GP, Vasudevan T. Studies with porous zinc electrodes with additives for secondary alkaline batteries. J Power Sources. 1998 Sept; 75:90-100, DOI: 10.1016/S03787753(98)00096-2.

20. Lee $\mathrm{SH}$, Yi CW, Kim K. Characteristics and electrochemical performance of the $\mathrm{TiO}_{2}$-coated $\mathrm{ZnO}$ anode for Ni-Zn secondary batteries. J Phys Chem C. 2011 Dec; 115:2572-7, 2011. DOI: 10.1021/jp110308b.

21. Zeng D, Yang Z, Wang S, Ni X, Ai D, Zhang Q. Preparation and electrochemical performance of Indoped ZnO as anode material for Ni-Zn secondary cells. Electrochim Acta. 2011 Apr; 56:4075-80. DOI: 10.1016/j.electacta.2011.01.119. 
22. Hilder M, Winther-Jensen B, Clark NB. The effect of binder and electrolyte on the performance of thin zinc-air battery. Electrochim Acta. 2012 May; 69:308-14. DOI:10.1016/j.electacta.2012.03.004.

23. Masri MN, Nazeri MFM, Ng CY, Mohamad AA. Tapioca binder for porous zinc anodes electrode in zincair batteries. J King Saud University-Engineering Sci. 2015 July; 27:217-24. DOI: 10.1016/j.jksues.2013.06.001.

24. Lee CW, Eom Sw, Sathiyanarayanan K, Yun MS. Preliminary comparative studies of zinc and zinc oxide electrodes on corrosion reaction and reversible reaction for zinc/air fuel cells. Electrochim Acta. 2006 Dec; 52:1588-91. DOI: 10.1016/j.electacta.2006.02.063.

25. Müller S, Holzer F, Haas O. Optimized zinc electrode for the rechargeable zinc-air battery. J Appl Electrochem. 1998 Sept ; 28:895-8. DOI: 10.1023/A:1003464011815.

26. Wu GM, Lin SJ, Yang CC. Alkaline Zn-air and Al-air cells based on novel solid PVA/PAA polymer electrolyte membranes. J Membr Sci. 2006 Sept; 280:802-8. DOI: 10.1016/j.memsci.2006.02.037.

27. Yang CC, Lin SJ. Alkaline composite PEO-PVA-glassfibre-mat polymer electrolyte for Zn-air battery. J Power Sources. 2002 Nov; 112:497-503. DOI: 10.1016/S0378-7753(02)00438-X.

28. Masri MN, Mohamad AA. Effect of adding potassium hydroxide to an agar binder for use as the anode in Zn-air batteries. Corros Sci. 2009 Dec; 51:3025-9. DOI: 10.1016/j.corsci.2009.08.027.

29. Ein-Eli Y, Auinat M, Starosvetsky D. Electrochemical and surface studies of zinc in alkaline solutions containing organic corrosion inhibitors. J Power Sources, 2003 Mar; 114:330-7. DOI: 10.1016/S03787753(02)00598-0.

30. Saleem M, Sayyad MH, Karimov KHS, Ahmad Z. Fabrication of investigation of the charge-discharge characterization of Zinc-PVA-KOH-Carbon Cell. Acta Phys Pol A. 2009 Dec; 116:1021-4. DOI: 10.12693/APhys/PolA.116.1021.

31. Wu Q, Zhang J, Sang S. Preparation of alkaline solid polymer electrolyte based on $\mathrm{PVA}-\mathrm{TiO} 2-\mathrm{KOH}-\mathrm{H}_{2} \mathrm{O}$ and its performance in Zn-Ni battery. J Phys and Chem Solids. 2008 Nov; 69, 2691-5. DOI: 10.1016/j.jpcs.2008.06.132.

32. Payer G, Ebil Ö. Zinc electrode morphology evolution in high energy density nickel-zinc batteries. J Nanomater. 2016 Feb; 2016:1-9. DOI: 10.1155/2016/1280236.

33. Brett CMA, Brett AMO, editor. Electrochemistry: Priciples, Methods, and Applications. Oxford University Press; 1994. ISBN: 978-0198553885.

34. Gileadi E, editor. Electrode Kinetic for Chemists, Chemical Engineers, and Materials Scientists. John Wiley \& Sons; 1993. ISBN: 978-0-471-18858-2. 
35. Minakshi M, Appadoo D, Martin DE. The anodic behavior of planar and porous zinc electrodes in alkaline electrolyte. Elctrochem Solid-State Lett. 2010 Jan; 13:A77-80. DOI: 10.1149/1.3387672.

36. Chen T, Pan L, Loh TAJ, Chua DHC, Yao Y, Chen Q, Li D, Qin W, Sun Z. Porous nitrogen-doped carbon microspheres as anode materials for lithium ion batteries. Dalton Trans. 2014 Jun; 43:14931-3-5. DOI: 10.1039/C4DT01223B. 
